\title{
How Does Self-Regulation Affect Computer-Programming Achievement in a Blended Context?*
}

\author{
Harun Cigdem \\ Turkish Land Forces Non-Commissioned Officer Vocational College, Turkey
}

\begin{abstract}
This study focuses on learners' self-regulation which is one of the essential skills for student achievement in blended courses. Research on learners' self-regulation skills in blended learning environments has gained popularity in recent years however only a few studies investigating the correlation between self-regulation skills and student achievement in blended learning environments exist. Self-regulation is related to self-efficacy, anxiety, interactivity, satisfaction with and usefulness of the system. Self-regulated learners are more likely to accomplish at online learning. In this study, a total of 267 military vocational college students were taught computer programming during a 15 -week-long semester in a blended learning context, which involved using both face to face teaching and online learning through MOODLE over intranet. Participants were the graduates of vocational high schools and the students at the departments of Computer Technologies and Electronics \& Communication Technologies and were all male. Liaw and Huang's Self-Regulation Scale with six subscales was used to collect the data during the last two weeks of instruction. Regression analyses were conducted to analyze the data. The results revealed that self-regulation was affected by perceived anxiety, interactivity in the online learning environment, and perceived self-efficacy. Learners' academic achievement has been affected only by perceived self-efficacy.
\end{abstract}

Keywords: Blended learning; Computer programming course; Course achievement; Interactivity; Self-regulation; Perceived self-efficacy

\section{Introduction}

Over the past two decades, developments in internet technologies have affected every aspect of our lives and have also changed the face of education, teaching and learning (Altun, Gulbahar \& Madran, 2008; Yukselturk \& Bulut, 2007). Throughout these developments, online learning that makes new educational practices available for students, which was not possible in traditional classroom settings, has become a noteworthy method. Researchers and educational institutions have devoted great efforts to build up online learning environments for their students to share and obtain information. Online learning environments deliver more interactive and independent learning experience for learners at anytime and anywhere (Khan, 1997; Michailidou \& Economides, 2003; Moore, \& Kearsley, 1996). Because of the independent characteristics of this learning

\footnotetext{
${ }^{*}$ The author is an officer at Turkish Army. The views expressed in this study are those of the author and do not necessarily reflect the official policy or position of the Turkish Military Forces.
} 
environment, students are increasingly expected to take greater responsibility for the control of their own learning needs (Artino, 2007; Dabbagh \& Kitsantas, 2004; Schunk \& Zimmerman, 1998). However, when they have to self-regulate their study while using online environments, in the absence of an instructor students' motivation decreases (Lynch \& Dembo 2004), so learners still need teachers and traditional classroom setting (Ting \& Chao, 2013). As a possible solution to this problem, educational institutions all around the world have focused on blended learning (Allen, Seaman, \& Garrett, 2007) which is based on the use of appropriate technology and choice of the most suitable instructional methods to manage teaching (Osguthorpe \& Graham 2003).

\section{Blended Learning}

Blended learning is defined as using key features of face to face and online instructional methods (Akkoyunlu \& Soylu, 2008; Lynch \& Dembo, 2004; Owston, York, \& Murtha, 2013). Blended learning provides many advantages to all stakeholders in an educational system. For instance, blended learning empowers productive use of classroom area; faculty members take advantage of enhanced adaptability in their instruction processes; students' active learning increases, students take responsibility on their own learning, learners become more gratified and get higher points than pure face-to-face or pure web based classes (Cavanagh, 2011; Vaughan, 2007). In a flexible online mode of blended learning environment, the content of a course is easier to access for students and students can study at their own pace via the Web which plays an important role on learner satisfaction and level of achievement (Chen, Stocker, Wang, Chung, \& Chen, 2009; Liao, 2007).

Although blended courses are increasing rapidly, research on what influences student performance in such an environment is not fully understood (Tabak \& Nguyen, 2013) and little is known about factors contributing to achievement in these self-regulated online learning environments (Artino, 2009). For this reason, other researchers believe that factors affecting students' academic achievement in online mode of blended courses still needs to be identified (Yukselturk \& Bulut, 2007). As online learning environments are becoming more individualized, user-centered, connected, ubiquitous and stable, students are required to become proficient in mastering their own learning processes, which means becoming a self-regulated student (Artino, 2007; Delen, Liew \& Willson, 2014; Motiwalla, 2007; Schunk \& Zimmerman, 1998).

\section{Self-Regulated Learning (SRL)}

Self-regulated learning (SRL), has been described as an active, constructive process where learners plan and set goals prior to learning, monitor their learning progress, and then self-evaluate their performance after learning (Pintrich, 2000; Zimmerman, 2008). SRL helps students learn effectively and performance better (Zimmerman, 2002).

Researchers have reached a consensus that students' abilities to use of self-regulated strategies have been positively associated with students' achievement in and satisfaction with online courses (Artino, 2008; Artino, 2009; Lee, Shen, \& Tsai, 2008; Liaw \& Huang, 2013; Paechter, Maier \& Macher, 2010; Pintrich, 2000; Puzziferro, 2008; Wang, Shannon \& Ross, 2013; Yukselturk \& Bulut, 2007). Previous studies showed that students, who failed to use self-regulatory actions in learning time, 
could not learn effectively in online learning environments (Azevedo \& Cromley, 2004). Contrary to these studies, Ergul (2004) did not find a significant relationship between academic achievement and self-regulation.

Many studies examining relationship between SRL and students' achievement in face to face teaching environments conducted (Kramarski \& Gutman, 2006; Miltiadou \& Savenye 2003, Zimmerman 1986) and studies examining relationship SRL and students' success in distance and online learning environments begin to emerge(Kitsantas \& Dabbagh, 2004; Lynch \& Dembo, 2004; Ting \& Chao, 2013; Whipp \& Chiarelli, 2004). In addition to this, more studies are needed in order to determine successful learners' characteristics in blended learning environments.

To identify factors affecting students' success in a blended Computer Programming course, this paper uses SRL variables of a conceptual model proposed by Liaw and Huang (2013). According to Liaw and Huang (2013), learner self-regulation (LSR), as a dependent factor, could be predicted by independent factors including perceived self-efficacy (PSE), perceived anxiety (PA), interactivity in the online learning environment (ILE), perceived satisfaction (PS), and perceived usefulness (PU). Learner self-regulation and these five properties were chosen to be notably considerable for blended learner's achievement.

\section{Perceived Self Efficacy (PSE)}

Students' self-beliefs about their academic capabilities play an important role in improving their academic performance (Cigdem \& Yildirim, 2014). Self-efficacy is described as individual's confidence in individual's capability to organize and implement activities necessary to achieve specific goals (Bandura, 1997; Zimmerman, 1989). The level of PSE might be used as a reliable indicator in order to predict a learner's achievement (Askar \& Davenport, 2009) including blended courses. From this point of view, students with higher PSE toward learning in online courses are usually more motivated, more persistent and perform better in these courses (Ergul, 2004; Linnenbrink \& Pintrich, 2002; Lynch \& Dembo, 2004). On the other hand, with a lower PSE, learners will have negative thoughts related to requested task, perceive them not as challenging but threatening and feel confused or even got lost when they meet new technologies (Simsek, 2011). For this reason, learners set inadequate objectives for themselves (Bandura, 1997) when they have low PSE.

Previous researchers have found conflicting results related to relationship between PSE of technology and students' performance and satisfaction with online courses. Wang and Newlin (2002) found that performance of an online course can be predicted from PSE of online technologies. Joo, Bong, and Choi (2000) examined relationship between PSE and learners' performance in Web-based instruction. They found that PSE of technologies is a significant variable that may determine learners' performance in distance education. In Lynch and Dembo's (2004) study, among the attributes assessing to predict achievement in a blended learning course, PSE for learning performance was one of two primary predictors of learner's achievement. A learner's PSE of online learning may be a key predictor of student success. In another study, Bell and Akroyd (2006) found that learners' PSE was one of the most powerful predictors of achievement. 
On the other hand, Puzziferro (2008) examined college level students' PSE of online technologies and SRL as predictors of achievement and satisfaction in online courses and it was found that PSE of online technologies were not correlated with achievement while self-regulation significantly related performance. DeTure's (2004) study found that PSE of online technologies was a weak predictor of achievement in online courses.

Wiedenbeck, LaBelle and Kain (2004) found that PSE of programming has a direct effect on achievement in a programming course. Contrary to theoretical expectations, Wilson and Shrock's (2001) study did not find a significant effect of programming self-efficacy on introductory computer programming course outcomes.

Considering the relationship between PSE and other self-regulation factors, higher PSE tended to increase perceived satisfaction (Artino, 2007) and perceived usefulness of online learning systems (Liaw \& Huang, 2013). On the other hand, Madorin and Iwasiw (1999) and Lee (2006) found PSE did not have a positive relationship with the perceived usefulness.

\section{Perceived Anxiety (PA)}

Computer anxiety is defined as a fear felt by individuals when they are using computers (Chua, Chen, \& Wong, 1999). PA may be a serious barrier against the acquisition of computer skills (Simsek, 2011), satisfaction (Sun, Tsai, Finger, Chen, \& Yeh, 2008) and self-efficacy (Simsek, 2011).

PA was found to be an important factor that could influence online learning achievement in higher education institutions (Ndubisi, 2004; Saadé \& Kira 2006). In online environments, PA had negatively correlated with learners' self-regulation (Tsai, 2009) meaning that learners' with high level of PA would not perform well while learners with lower PA would perform better in blended learning environments.

\section{Interactivity in the Online Learning Environment (ILE)}

Interactivity in both face to face instruction and online mode of blended learning is important, regardless of which instructional method and technology is used (Moore \& Kearsley, 1996). Using suitable technology efficiently with pedagogy enhances interactivity between students and online resources (Jain, 2011). Online environment allows learners to be self-regulated by exploring and playing with the course material (Michailidou \& Economides, 2003). The level of interactivity out of the classroom influences achievement in blended courses (Bliuc, Ellis, Goodyear, \& Piggott, 2011; Smyth, Houghton, Cooney, \& Casey, 2012).

ILE is a decisive element for improving learners' positive feelings such as perceived satisfaction (Yukselturk \& Yildirim, 2008), perceived usefulness, and SRL in online environments (Liaw \& Huang, 2007; Sharma, Dick, Chin, \& Land, 2007), which means affectionate interactivity in online learning environments may augment SRL of learners toward online learning (Vighnarajah, Wong, \& Kamariah, 2009). Some facilities of online learning environment such as synchronous or 
asynchronous learning activities have effect on students' perceived satisfaction with technology (Cigdem \& Topcu, 2013; Sahin \& Shelley, 2008; Sumak, Hericko, \& Pusnik, 2011).

\section{Perceived Satisfaction (PS)}

Perceived satisfaction (PS) is described as one's perception of information systems and the level of comfort while practicing them (Liaw \& Huang, 2013). PS is constantly used to evaluate a system's success or failure. Individuals' perception and attitudes towards the use of the system are influenced by individuals' characteristics and experiences. In a blended learning environment, PS is an important factor to assess the effectiveness of instructional method implemented in an online learning environment and also insufficient PS emerged to be a barrier to implement online mode of blended courses successfully (Akkoyunlu \& Soylu, 2008; Lo, 2010; Melton, Graf, \& Chopak-Foss, 2009; Paechter, Maier, \& Macher, 2010). Perceived usefulness could be a predictor of learner's satisfaction (Johnson, Hornik, \& Salas 2008) with online learning environment.

A majority of research studies show that learners have more satisfied with blended courses, than pure face-to-face or pure online approaches of education (Owston, York, \& Murtha, 2013). Wang, Shannon and Ross (2013) suggested that learner's PS affects the successful completion of the online course. When learners have higher PS in their online course, they tend to earn higher grades (Puzziferro, 2008). Therefore, when learners are satisfied with learning online course content, results of online course might be successful.

\section{Perceived Usefulness (PU)}

The level that a person thinks using a certain system would improve his/her job performance within an organizational content is described as PU (Davis, 1989, p. 320). PU of the online mode of blended learning programs is another influential factor for academic achievement. Studies on online learners have revealed that PU positively predicts students' academic performance and satisfaction (Cigdem \& Topcu, 2013; Johnson, Hornik, \& Salas, 2008; Liaw, 2008; Miltiadou \& Savenye, 2003). Numerous studies (Adams, Nelson, \& Todd, 1992; Davis, 1989; Davis, Bagozzi, \& Wharshaw, 1989) informed that one's acceptance of an information technology system is specified by PU. Joo, Lim and Kim (2012), suggested that PU is one of the most powerful factors for achievement.

In summary, this literature review provides conflicting evidence regarding the relationship between SRL, PSE, PA, ILE, and PS - and student achievement. In addition, there is no prior research that has examined relationship between all self-regulation factors and student achievement simultaneously. Researchers would benefit from measuring self-regulation capabilities of learners especially for online learning and blended learning environments, because research continues to point out a positive correlation between learners' self-regulation skills and their academic achievement (Chang, 2007).

This study was designed to determine the relationship between SRL, PSE, PA, ILE, and PS of online mode of blended course - and student achievement in a blended Computer Programming course, based on the conceptual model proposed by Liaw and Huang (2013). In doing so, this study 
contributes to our understanding of how students learn in online mode of blended environment. Through on an investigating of these relationships, it will be possible to plan and design better online mode of blended courses for learners with various characteristics.

The purpose of this study was to gain an understanding of the relationship between LSR, PS, PU, PSE, and PA - and course grade (CG) of students in blended Computer Programming course in a military vocational college context. In the light of this main objective, this study aimed to answer the following research questions:

- Is there any significant correlation between student's success and learner self-regulation, perceived usefulness, perceived satisfaction, perceived self-efficacy, perceived anxiety, and interactivity in the online learning environment?

- Can learner self-regulation be predicted from perceived satisfaction, perceived usefulness, and interactivity in the online learning environment?

- Can perceived satisfaction be predicted from interactivity in the online learning environment, perceived anxiety, and perceived self-efficacy?

- Can perceived usefulness be predicted from interactivity in the online learning environment, perceived anxiety, and perceived self-efficacy?

- Can student success be predicted from learner self-regulation, perceived usefulness, perceived satisfaction, perceived self-efficacy, and perceived anxiety?

\section{Method}

\section{Participants}

Convenient sampling method was used since the researcher works at the college where the participants were attending lessons. Participants of this study included 267 military vocational college students with blended learning experiences at Computer Programming Course during the first semester of the 2013-2014 academic year. All participants were male as it was a military vocational and technical college and participants were living on the college campus that is a limitation for the entire study. With regard to department, some of them were from the Department of Computer Technologies $(n=55)$, and the others were from the Department of Electronic and Communication Technologies $(n=212)$. The participants' age differed from 18 to 23 with an average of 20 (SD =0.99). Most participants graduated from vocational high schools $(n=229)$, and the others graduated from general high schools $(n=38)$. Lastly, most of the participants didn't have an online education experience $(n=226)$, while the remains had $(n=41)$.

\section{Blended Computer Programming Course}

Computer programming is generally perceived as complex and hard, especially for beginners. With a lower self-efficacy of programming skills, learners may be unsuccessful in Computer Programming course (Askar \& Davenport, 2009; Derus \& Ali, 2014). When static media were employed in teaching the dynamic concepts of programming, the problem worsens (Linden \& Lederman, 2011) and this method for the computer programming course is preferred by many instructors (Uysal, 2014). 
The computer programming course was a must for the departments of Computer Technologies and Electronics and Communication Technologies in the study. Computer Programming course concerns almost all programming specialties and comprises a vast body of computer programming knowledge and skills which increase continuously and are needed for other courses such as Internet Programming, Object Oriented Programming and Microprocessors. Thus, course subjects have to be taught efficiently in limited class time. Therefore, the lecturer designed Computer Programming course in a blended course format and specified intended learning objectives at the beginning of the course. Learning management system of college is named as Course Portal.

Computer Programming Course was offered for 15 weeks including 100-minute face-to-face lecture in every week. In each face-to-face session, students were presented with the content of the week. After the lecture, students created C\# projects in computer labs. A short summary and feedback related to common mistakes were provided at the end of each session. Students who could not participate in or had difficulty in understanding the face-to-face lectures were expected to log onto the course website individually through intranet.

In online mode of Computer Programming course environment, lecturer provided lecture notes, presentations, sample projects, learning activities and videos over the intranet on MOODLE, a wellknown learning management system. In recent years, with the development of learning management systems and elimination of technological barriers of video production, videos related to basic programming such as "variables, if-else statements and for-while loops" were produced by the lecturer. Macromedia Captivate and Camtasia Studio were used for videos by screen capturing. These videos were uploaded to learning management system and named as "Programming in Five Minutes". The lecturer expected students to watch videos before the lesson and use class time efficiently for in-class projects. Students were able to review the videos at anywhere and anytime in the college campus. Online mode of blended Computer Programming course gave learners to control what subject they want to study/work on. One of the screenshot examples of the course website and video simulations can be seen in Figure 1 and Figure 2. 


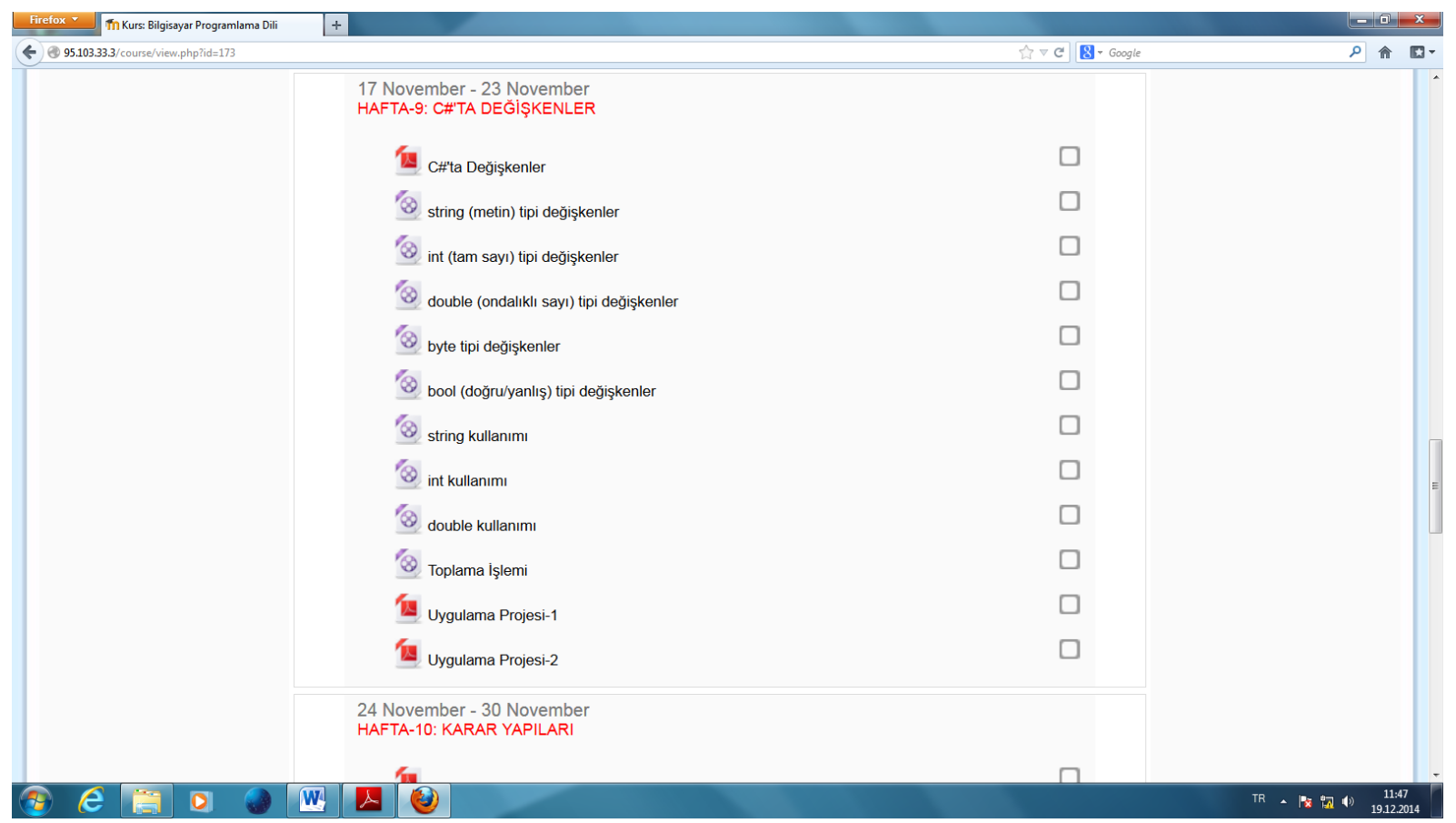

Figure 1. A screenshot of Computer Programming Website

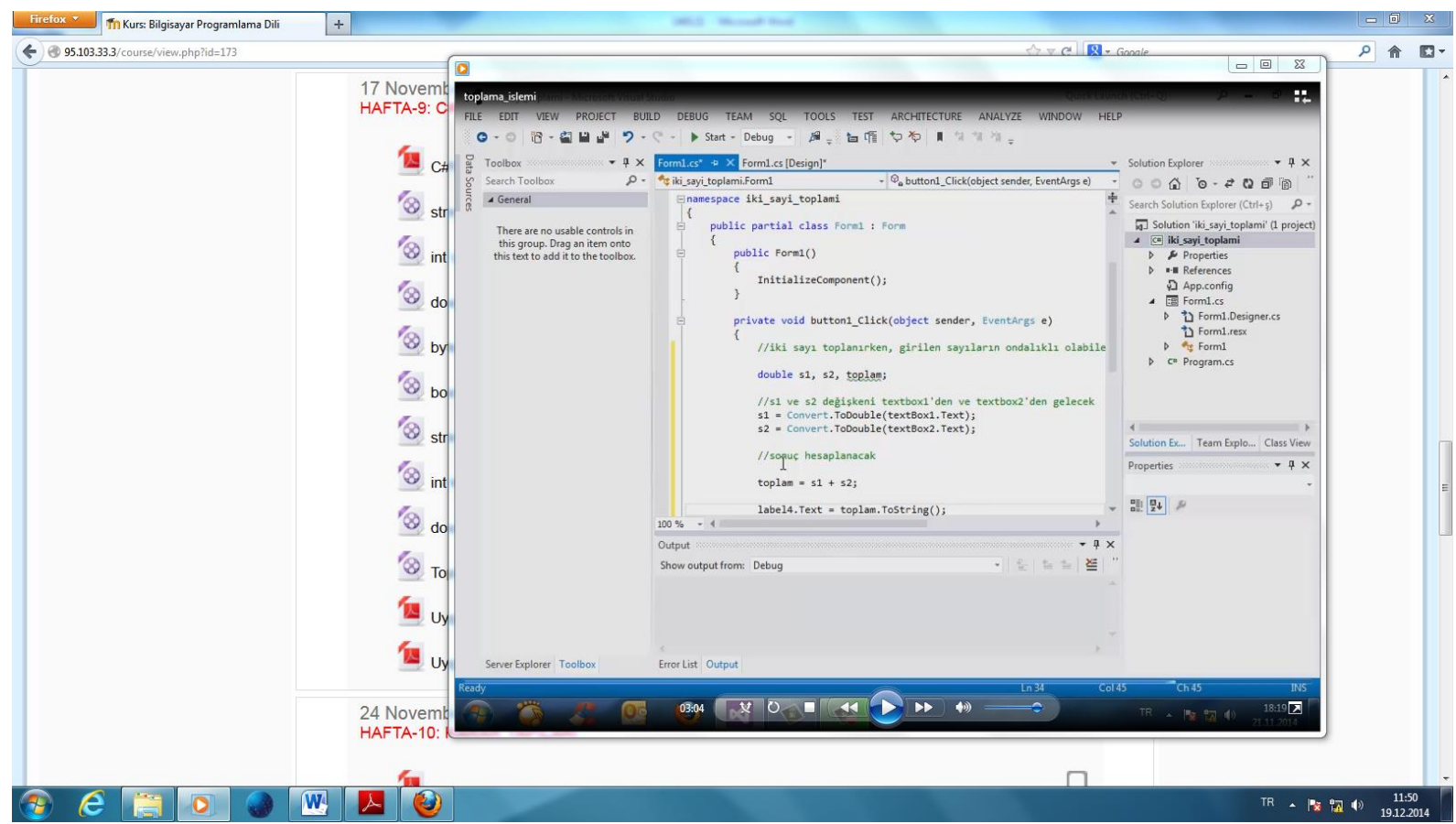

Figure 2. A screenshot of video simulation captured by Camtasia Studio

In blended Computer Programming course, students were expected to take more responsibility for their own learning and study at their own pace as self-regulated learners. 


\section{Data Collection Instruments}

An online questionnaire was used as data collection tool. The questionnaire was divided into two sections. The first section was related to demographical characteristics and the second section of the questionnaire was the Learner Self-Regulation Scale, validated by Liaw and Huang (2013).

In order to measure learner self-regulation (LSR) in online mode of blended Computer Programming course, Learner Self-Regulation Scale was used in the study. There were 30 five-point Likert-type items with a response scale 5 (strongly agree) to 1 (strongly disagree), which include six factors. The scale focused on responses relating to ILE, PSE, PA, PS, PU and LSR, with regard to the online mode of blended learning system. As an example for items placed in each subscale, the following items were supplied. "I feel confident using Course Portal" (PSE), "Using Course Portal make me feel anxious." (PA), "I believe Course Portal can assist teacher-learner interaction." (ILE), "I am satisfied with using Course Portal functions." (PS), "I believe using Course Portal is effective for learning." (PU), and "Course Portal is an individual learning tool." (LSR). To determine internal consistency of the scale, reliability analyses were conducted. The overall Cronbach's alpha coefficient for the questionnaire was 0.90 .

Table 1. Alpha Coefficients of Scale

\begin{tabular}{llcc}
\hline Subscale & Items & Liaw and Huang (2013) & Current Study \\
\hline Perceived self-efficacy & 4 & 0.91 & 0.79 \\
Perceived anxiety & 4 & 0.94 & 0.78 \\
Interactivity in the online & 6 & 0.93 & 0.74 \\
learning environment & & 0.94 & 0.84 \\
Perceived satisfaction & 5 & 0.96 & 0.82 \\
Perceived usefulness & 6 & 0.93 & 0.77 \\
Learner self-regulation & 5 & 0.95 & 0.90 \\
\hline TOTAL & 30 & & \\
\hline
\end{tabular}

Reliability analyses revealed that all the subscales had good internal consistency reliabilities. The comparative values of reliability analyses for the six subscales are given in Table 1 . The differences in these results could be due to different samples, cultures or online learning environment selection.

Students' official Computer Programming course final exam grades were obtained from the students' affairs information system.

\section{Data Analysis}

Pearson correlation and linear regression analyses were performed to analyze the data in order to address the research questions. 


\section{Results}

The correlations between self-regulation factors and students' course grades were presented in Table 2. Simple correlations of all the variables in the study revealed that students' course grades were significantly correlated with perceived self-efficacy and perceived usefulness $(p<.005)$. As the correlation indicated a positive value, as students' perceived self-efficacy and perceived usefulness increase, students' course grades also increase.

Table 2. Correlations between students' course grade and self-regulation factors

\begin{tabular}{lcccccc}
\hline & PSE & PA & ILE & PS & PU & LSR \\
\hline Course Grade & $.181^{* *}$ & -.075 & .071 & .115 & $.128^{*}$ & .070 \\
\hline
\end{tabular}

${ }^{*}$ Correlation is significant at the 0.05 level (2-tailed).

**Correlation is significant at the 0.01 level (2-tailed).

The second research question was about predicting learner self-regulation from perceived satisfaction, perceived usefulness, and interactivity in the online learning environment. Perceived satisfaction, perceived usefulness, and interactivity in the online learning environment were the independent variables predicting learner self-regulation scores. The analysis returned significant results, $R^{2}=.725, F(3,263)=234.483, p<.001$; it turned out that perceived satisfaction, perceived usefulness and interactivity in the online learning environment significantly affect the learner selfregulation scores (see Table 3).

Table 3. Regression results predicting LSR from PS, PU, and ILE

\begin{tabular}{llllll}
\hline Variable & $B$ & $S E$ & $b$ & $t$ & $p$ \\
\hline PS & 0.383 & 0.072 & 0.358 & 5.311 & .000 \\
PU & 0.236 & 0.060 & 0.264 & 3.940 & .000 \\
ILE & 0.238 & 0.045 & 0.290 & 5.244 & .000 \\
\hline
\end{tabular}

The third research question about predicting perceived satisfaction from interactivity in the online learning environment, perceived anxiety, and perceived self-efficacy revealed significant results, $\mathrm{R}^{2}$ $=.731, F(3,263)=242.442, p<.001$; however, it turned out that interactivity in the online learning environment and perceived self-efficacy significantly affect the perceived satisfaction scores positively, whereas perceived anxiety significantly affects the perceived satisfaction scores negatively (see Table 4).

Table 4. Regression results predicting PS from ILE, PA, and PSE

\begin{tabular}{llllll}
\hline Variable & $B$ & $S E$ & $b$ & $t$ & $p$ \\
\hline ILE & 0.399 & 0.032 & 0.519 & 12.663 & .000 \\
PA & -0.108 & 0.031 & -0.122 & -3.469 & .001 \\
PSE & 0.402 & 0.048 & 0.368 & 8.439 & .000 \\
\hline
\end{tabular}


The fourth research question about predicting perceived usefulness from interactivity in the online learning environment, perceived anxiety, and perceived self-efficacy also indicated significant results, $\mathrm{R}^{2}=.679, F(3,263)=188.335, p<.001$. It turned out that interactivity in the online learning environment and perceived self-efficacy significantly affect the perceived usefulness scores (see Table 5).

Table 5. Regression results predicting PU from ILE, PA, and PSE

\begin{tabular}{llllll}
\hline Variable & $B$ & $S E$ & $b$ & $t$ & $p$ \\
\hline ILE & .528 & .041 & .573 & 12.778 & .000 \\
PA & -.073 & .041 & -.068 & -1.773 & .077 \\
PSE & .396 & .062 & .302 & 6.335 & .000 \\
\hline
\end{tabular}

The fifth research question was about the students' course grade received after accomplishing the course requirements. Course scores were predicted from self-regulation factors of PSE, PA, PU, PS and LSR. The analyses returned significant results, as well, $R^{2}=.044, F(5,261)=2.428, p<.005$.

Table 6. Regression results predicting Students' Course Grade from PSE, PA, PU, PS, and LSR

\begin{tabular}{llllll}
\hline Variable & $B$ & $S E$ & $b$ & $t$ & $p$ \\
\hline PSE & 1.817 & .721 & .244 & 2.519 & .012 \\
PA & .015 & .412 & .003 & .037 & .970 \\
PU & .766 & .717 & .135 & 1.068 & .286 \\
PS & -.227 & .945 & -.033 & -.240 & .810 \\
LSR & -1.171 & .726 & -.184 & -1.613 & .108 \\
\hline
\end{tabular}

Only perceived self-efficacy appeared to significantly contribute to students' course grade (see Table 6). However, the remaining variables, though they were not statistically significant contributors of the course grade, did not have a significant effect on course grade. None of the other predictor variables made significant contributions to the regression model.

At the end of prediction based linear regression analyses following figure was drawn (Figure 3).

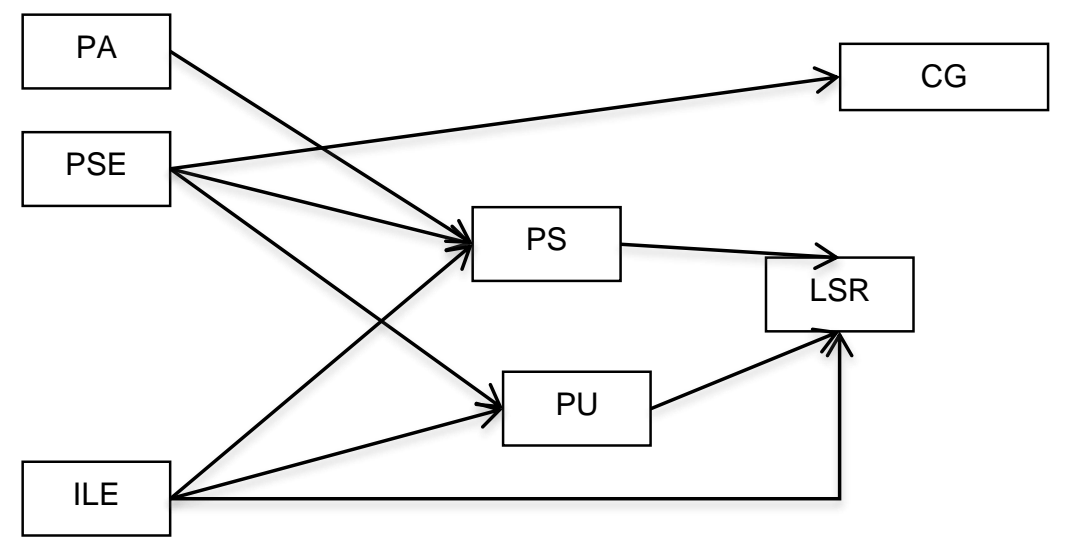

Figure 3. Derived Model 
Based on the derived model, perceived self-efficacy affected the achievement in the Computer Programming course. That is, learners with a higher level of perceived self-efficacy of online learning indicated a higher level of course grades when taking blended Computer Programming course. Learners who were more satisfied with the online mode of blended learning, and found it is more interactive and useful, reported a higher level of self-regulation in online mode of blended Computer Programming course.

\section{Discussion and Conclusion}

Military vocational college has offered courses in blended format since the 2012-2013 academic year. In order to design blended learning in accordance with the needs of the students, it is necessary to inquire what will help students' success and characteristics of successful learners (Yukselturk \& Bulut, 2007). The main purpose of the current study was to inquire which selfregulation factors can predict learner success in a blended computer programming course.

The current study did not find a significant relationship between learner self-regulation and achievement in blended Computer Programming course, which is a similar result to Ergul's (2004) study that examined relationship between learners' characteristics and academic achievement in distance education. This finding contradicts with the previous research results that found learner self-regulation as a predictor of achievement (Paechter, Maier, \& Macher, 2010; Puzziferro, 2008). Hence, there should be regulations especially in online mode of blended learning that would enhance learner self-regulation such as online quizzes, online assignments and so on.

Correlation among learner self-regulation factors and students' success in computer programming course showed perceived self-efficacy and perceived usefulness were significantly and positively correlated with course grades while the other factors were not. The results of the present study show that there is a meaningful positive correlation between perceived usefulness and course grades. This parallels with Joo, Lim and Kim's (2012) findings.

The results revealed that perceived self-efficacy was the strongest positive significant predictor of course grades. The results suggest that students with higher levels of perceived self-efficacy of online mode of blended learning tend to receive better grades. The significant correlation between perceived self-efficacy and achievement in this study was also supported by the self-efficacy theory (Bandura, 1997) and the findings of other research (Ergul, 2004; Joo, Bong, \& Choi, 2000; Lynch \& Dembo, 2004; Wang \& Newlin, 2002;). It unfolds that the college students with higher self-efficacy have higher course grade in Computer Programming Course, like in Wiedenbeck, LaBelle and Kain's (2004) study. The results of this study support Bell and Akroyd (2006), Joo, Bong and Choi's (2000), Lynch and Dembo's (2004), Wang and Newlin's (2002) and Wang, Shannon and Ross's (2013) findings that perceived self-efficacy of technologies was one of the best predictors of learner's achievement. On the other hand, our results did not support Wilson and Shrock's (2001), DeTure's (2004) and Puzziferro's (2008) studies that failed to find a significant relationship between perceived self-efficacy and achievement in online courses. This suggests that learners who want to succeed in blended learning should have confidence in using online mode of blended learning environment. 
In opposition to the researchers' findings (Lo, 2010; Melton, Graf, \& Chopak-Foss, 2009; Paechter, Maier \& Macher, 2010), students perceived satisfaction can be considered a factor for successful learning, the current study did not find a significant relationship between achievement and students' satisfaction of e-learning system.

The connection between the learner self-regulation and the exterior variables was investigated throughout regression analyses. This study unfolded that perceived satisfaction was the strongest predictor of learner self-regulation. Results of the current study were also consistent with previous research that found that self-regulated strategies have been positively associated with satisfaction with online courses (Artino, 2008; Artino, 2009; Lee, Shen, \& Tsai, 2008; Liaw \& Huang, 2013; Pintrich, 2000; Puzziferro, 2008; Wang, Shannon, \& Ross, 2013; Yukselturk \& Bulut, 2007).

More than anything else, perceived usefulness and interactivity in the online learning environment were significant predictors of learner self-regulation in online mode of blended learning environments. The results of this research support the former research that learner self-regulation could be influenced by perceived satisfaction, perceived usefulness, and interactivity in the online learning environment (Kramarski \& Gutman, 2006; Liaw \& Huang, 2013).

Interactivity in the online learning environment, perceived anxiety, and perceived self-efficacy factors were significantly correlated with perceived satisfaction. The results of this research are parallel to former studies and support them (Kramarski \& Gutman, 2006; Liaw, 2008; Motiwalla, 2007). This means that perceived self-efficacy and interactivity in the online learning environment are significant factors that affect perceived satisfaction. Consistent with the former findings, the present study on the field in military vocational education provides a supporting extension for existing literature on the significant and positive relationship between perceived satisfaction and perceived usefulness (Cigdem \& Topcu, 2013; Davis, Bagozzi, \& Wharshaw, 1989; Johnson, Hornik, \& Salas, 2008; Liaw, 2008; Sun, Tsai, Finger, Chen, \& Yeh, 2008).

In opposition to the conceptual model adopted in this study, perceived anxiety was not in any significant relationship with perceived usefulness while interactivity in the online learning environment and perceived self-efficacy factors were significantly related with perceived usefulness. It means that perceived usefulness of e-learning environment can be affected by interactivity in the online learning environment and perceived self-efficacy. Regarding the effect of interactivity in the online learning environment and perceived self-efficacy on perceived usefulness, the result supports the previous study by Liaw (2008) who claimed that multimedia instruction, interactive learning activities, and perceived self-efficacy predicted perceived usefulness. The significant correlation between perceived usefulness and interactivity in the online learning environment and perceived self-efficacy in this study also supported previous research (Liaw, 2008; Liaw \& Huang, 2007; Sharma, Dick, Chin, \& Land, 2007 ).

Students' characteristics should be taken into account while designing learning activities, for blended learning environments. If lecturers provide an introduction to using an online learning platform of blended courses, such as wathcing videos, how to download/upload assignments, checking grades online, as well as sending/receiving messages, students will be more satisfied with using the online learning platform. Finally, online courses should be conducted under a user-friendly platform to encourage students' persistent in using online mode of blended courses. If students find 
the e-learning environment easy to use, they would tend to think it is useful. The implication is that if students feel that e-learning is useful, their attitudes towards using it might be more positive.

\section{Limitations and Further Studies}

This study has several limitations. First of all, students' self-reported data were gathered by online questionnaire for this study. Secondly, regarding the sampling, the current study assessed military college students, and thus the applicability and generalizability of its findings are limited. The third limitation of the study is the gender issue; all of the participants were male due to the school structure of the military vocational school. All of the mentioned sampling problems limit the possibility to generalize the results. Therefore, the same study should be replicated within other contexts for further investigations in order to validate the findings.

Future research on learners' self-regulation should take gender and age factors into account in elearning environments. Additionally, future studies should explore the comparison of self-regulation by other variables such as culture, instructor, context and so on.

\section{References}

Adams, D., Nelson, R., \& Todd, P. (1992). Perceived usefulness, ease of use, and usage of information technology: A replication. MIS Quarterly, 16(2), 227-247.

Akkoyunlu, B. \& Soylu, M. Y. (2008). A Study of Student's Perceptions in a Blended Learning Environment Based on Different Learning Styles. Educational Technology \& Society, 11(1), 183-193.

Allen, I. E., Seaman, J., \& Garrett, R. (2007). Blending in: The extent and promise of blended learning education in the United States. Retrieved on 3 November 2014 from http://sloanconsortium.org/sites/default/files/Blending_In.pdf

Altun, A., Gülbahar, Y., \& Madran, O. (2008). Use of a Content Management System for Blended Learning: Perceptions of Pre-Service Teachers. Turkish Online Journal of Distance EducationTOJDE, 9(4),138-153.

Artino, A.R., Jr. (2007). Self-regulated learning in online education: A review of the empirical literature. International.Journal of Instructional Technology and Distance Learning, 4(6), 318.

Artino, A.R. (2008). Motivational beliefs and perceptions of instructional quality: Predicting satisfaction with online training. Journal of Computer Assisted Learning, 24, 260-270

Artino, A.R. (2009). Think, feel, act: motivational and emotional influences on military students' online academic success. J Comput High Educ, 21, 146-166.

Askar, P. \& Davenport, D (2009). An investigation of factors related to self-efficacy for Java programming among engineering students. Turkish Online Journal of Education Technology $8(1), 26-32$. 
Azevedo, R. \& Cromley, J.G. (2004). Does training on self-regulated learning facilitate students' learning with hypermedia? Journal of Educational Psychology, 96 (3), 523-535.

Bandura, A. (1997). Self-efficacy: The exercise of control. New York: W.H. Freeman.

Bell, P.D. \& Akroyd, D. (2006). Can factors related to self-regulated learning predict learning achievement in undergraduate asynchronous Web-based courses? International Journal of Instructional Technology and Distance Learning, 3(10), 5-16.

Bliuc, A.M., Ellis, R. A., Goodyear, P., \& Piggott, L. (2011). A blended learning approach to teaching foreign policy: Student experiences of learning through face-to-face and online discussion and their relationship to academic performance. Computers in Education, 56, 856-864.

Cavanagh, T.B. (2011). The blended learning toolkit: Improving student performance and retention. Educause Review, 34(4). Retrieved on 3 November 2014 from http://www.educause.edu/ero/article/blended-learning-toolkit-improving-studentperformance-and-retention

Chang, M.M. (2007). Enhancing web-based language learning through self-monitoring. Journal of Computer-Assisted Learning, 23, 187-196

Chen, S.W., Stocker, J., Wang, R. H., Chung, Y. C., \& Chen, M. F. (2009). Evaluation of selfregulatory online learning in a blended course for post-registration nursing students in Taiwan. Nurse Education Today, 29 (2009), 704-709.

Chua, S.L., Chen, D., \& Wong, A.F.L. (1999). Computer anxiety and its correlates: A meta-analysis. Computers in Human Behavior, 15, 609-623.

Cigdem, H. \& Topcu, A. (2013). Students' perception of e-learning in the technical vocational school. Science Journal of Turkish Military Academy, 23(2), 1-19.

Cigdem, H. \& Yildirim, O.G. (2014). Predictors of C\# programming language self efficacy among vocational college students. International Journal on New Trends in Education and Their Implications, 5(3), 145-153.

Dabbagh, N. \& Kitsantas, A. (2004). Supporting self-regulation in student-centered web-based learning environments. International Journal on E-Learning, 3(1), 40-47.

Davis, F.D. (1989). Perceived usefulness, perceived ease of use, and user acceptance of information technology. MIS Quarterly, 13(3), 319-340

Davis, F.D., Bagozzi, R.P. \& Warshaw, P.R. (1989). User acceptance of computer technology: A comparison of two theoretical models. Management Science, 35, 982-1003.

Derus, S.R. MD. \& Ali, A.Z.M. (2014). Integration of visualization techniques and active learning strategy in learning computer programming: a proposed framework. International Journal on New Trends in Education and Their Implications, 5(1), 93-103.

Delen, E., Liew, J., \& Willson, V. (2014). Effects of interactivity and instructional scaffolding on learning: Selfregulation in online video-based environments. Computers \& Education, 78, 312-320.

DeTure, M. (2004). Cognitive style and self-efficacy: Predicting student success in online distance education. American Journal of Distance Education, 18(1), 21-38. 
Ergul, H. (2004). Relationship between student characteristics and academic achievement in distance education and application on students of Anadolu University. Turkish Online Journal of Distance Education-TOJDE, 5(2), 81-90.

Jain, P.J. (2011). Interactions among online learners: A quantitative interdisciplinrary study. Education, 131(3), 538-544.

Johnson, R.D., Hornik, S., \& Salas, E. (2008). An empirical examination of factors contributing to the creation of successful e-learning environments. International Journal of HumanComputer Studies, 66 (5), 356-369.

Joo, Y.J., Bong, M., \& Choi, H. J. (2000). Self-efficacy for self-regulated learning, academic selfefficacy, and Internet self-efficacy in Web-based instruction. Educational Technology Research and Development, 48, 5-17.

Joo, Y.J., Lim, K.Y., \& Kim, S.M. (2012). A Model for Predicting Learning Flow and Achievement in Corporate e-Learning. Educational Technology \& Society, 15 (1), 313-325.

Khan, B.H. (1997). Web-based instruction. Englewood Cliffs, NJ: Educational Technology Publications.

Kitsantas, A., \& Dabbagh, N. (2004). Promoting self-regulation in distributed learning environments with web-based pedagogical tools: An exploratory study. Journal on Excellence in College Teaching, 15 (1\&2), 119-142.

Kramarski, B. \& Gutman, M. (2006). How can self-regulated learning be supported in mathematical e-learning environments? Journal of Computer Assisted Learning, 22, 24-33.

Lee, T.H., Shen, P.D., \& Tsai, C.W. (2010). Enhance students' computing skills via webmediated self-regulated learning with feedback in blended environment. International Journal of Technology and Human Interaction, 6(1), 15-32.

Lee, Y.C. (2006). An empirical investigation into factors influencing the acceptance of an e-learning system. Online Information Review,30(5), 517-541.

Liao, Y.K.C. (2007). Effects of computer-assisted instruction on students' achievement in Taiwan: A meta-analysis. Computers \& Education 48, 216-233.

Liaw, S.S. (2008). Investigating students' perceived satisfaction, behavioral intention, and effectiveness of e-learning: a case study of the Blackboard system. Computers \& Education, 51(2), 864-873.

Liaw, S.S. \& Huang, H.M. (2007). Developing a collaborative e-learning system based on users' perceptions. Lecture Notes in Computer Science, 4402, 751-759.

Liaw, S.S. \& Huang, H.M. (2013). Perceived satisfaction, perceived usefulness and interactive learning environments as predictors to self-regulation in e-learning environments. Computers \& Education, 60(1), 14-24.

Linden, T. \& Lederman, R. (2011). Creating visualizations from multimedia building blocks: A simple approach to teaching programming concepts. Information Systems Educators Conference. Wilmington, North Carolina, USA. 
Linnenbrink, E.A. \& Pintrich, P.R. (2002). Motivation as an enabler for academic success. The School Psychology Review 31(3), 313-327.

Lo, C.C. (2010). How student satisfaction factors affect perceived learning. Journal of the Scholarship of Teaching and Learning, 10(1), 47-54.

Lynch, R. \& Dembo, M. (2004). Online learning in a blended learning context. International Review of Research in Open and Distance Learning, 5(2), Retrieved 25 February2014 from http://www.irrodl.org/index.php/irrodl/article/view/189/271

Madorin, S. \& Iwasiw, C. (1999), The effects of computer-assisted instruction on the self-efficacy of baccalaureate nursing students. The Journal of nursing education, 38(6), 282-95.

Melton, B., Graf, J., \& Chopak-Foss, J. (2009). Achievement and satisfaction in blended learning versus traditional general health course designs. International Journal for the Scholarship of Teaching and Learning, 3(1), 26.

Michailidou, A. \& Economides, A. (2003). E-learn: Towards a collaborative educational virtual environment. Journal of Information Technology Education, 2, 131-152.

Miltiadou, M. \& Savenye, W.C. (2003). Applying social cognitive constructs of motivation to enhance student success in online distance education. AACE Journal, 11(1), 78-95.

Moore, M.G. \& Kearsley, G. (1996). Distance education: A systems view. Belmonth, CA: Wadsworth.

Motiwalla, L.F. (2007). Mobile learning: a framework and evaluation. Computers \& Education, 49(3), 581-596.

Ndubisi, N.O. (2004). Factors influencing E-learning adoption intention: examining the determinant structure of the decomposed theory of planned behaviour constructs. Paper presented at the HERDSA International Conference (pp. 252-62).

Osguthorpe, R.T., \& Graham, C.R. (2003). Blended learning systems: Definitions and directions. Quarterly Review of Distance Education, 4(3), 227-234.

Owston, R., York, D., \& Murtha, S. (2013). Student perceptions and achievement in a university blended learning strategic initiative. Internet and Higher Education, 18, 38-46.

Paechter, M., Maier, B., \& Macher, D. (2010). Students' expectations of and experiences in elearning: Their relation to learning achievements and course satisfaction. Computers \& Education, 54(1), 222-229.

Pintrich, P.R. (2000). A motivational science perspective on the role of student motivation in learning and teaching contexts. Journal of Educational Psychology, 95, 667-686.

Puzziferro, M. (2008). Online technologies self-efficacy and self-regulated learning as predictors of final grade and satisfaction in college-level online courses. American Journal of Distance Education, 22(2), 72-89.

Saadé, R.G. \& Kira, D. (2006). The emotional state of technology acceptance. Issues in Informing Science \& Information Technology, 3, 529-40.

Sahin, I. \& Shelley, M. (2008).Considering students' perceptions: The distance education student satisfaction model. Educational Technology \& Society, 11(3), 216-223. 
Schunk, D.H. \& Zimmerman, B. J. (Eds.). (1998). Self-regulated learning: From teaching to selfreflective practice. New York: The Guilford Press.

Sharma, S., Dick, G., Chin, W.W., \& Land, L. (2007). Self-regulation and e-learning. In Proceedings of the Fifteenth European Conference on Information System (pp. 383-394). St. Gallen: University of St. Gallen.

Simsek, A. (2011). The relationship between computer anxiety and computer self-efficacy. Contemporary Educational Technology, 2(3), 177-187.

Smyth, S., Houghton, C., Cooney, A., \& Casey, D. (2012). Students' experiences of blended learning across a range of postgraduate programmes. Nurse Education Today, 32, 464-468

Sumak, B., Hericko, M., \& Pusnik, M. (2011). A meta-analysis of e-learning technology acceptance: The role of user types and e-learning technology types. Computers in Human Behavior, 27(6), 2067-2077

Sun, P.C., Tsai, R.J., Finger, G., Chen, Y.Y., \& Yeh, D. (2008). What drives a successful e-learning? An empirical investigation of the critical factors influencing learner satisfaction. Computers \& Education, 50, 1183-1202.

Tabak, F. \& Nguyen, N.T. (2013). Technology acceptance and performance in online learning environments: Impact of self-regulation. MERLOT Journal of Online Learning and Teaching, 9(1), 116-130.

Ting, K. \& Chao, M. (2013). The application of self-regulated strategies to blended learning. English Language Teaching, 6(7), 26-32.

Tsai, C. C. (2009). Conceptions of learning versus conceptions of web-based learning: The differences revealed by college students. Computers \& Education, 53, 1092-1103.

Uysal, M.P. (2014). Improving first computer programming experiences: The case of adapting a web-supported and well-structured problem-solving method to a traditional course. Contemporary Educational Technology, 5(3), 198-217

Vaughan, N. (2007). Perspectives on blended learning in higher education. International Journal on E-Learning, 6 (1) , . 81-94.

Vighnarajah, Wong, S.L., \& Kamariah, A.B. (2009). Qualitative findings of students' perception on practice of self-regulated strategies in online community discussion. Computers \& Education, 53, 94-103.

Wang, A.T. \& Newlin, M.H. (2002). Online lectures: Benefits for the virtual classroom. THE Journal, $29,17-22$.

Wang, C., Shannon, D., \& Ross, M. (2013). Students' Characteristics, Self-Regulated Learning, Technology, Self-Efficacy, and Course Outcomes in Online Learning. Distance Education, 34(3), 302-323.

Whipp, J.L. \& Chiarelli, S. (2004). Self-regulation in a Web-based course: A case study. Educational Technology Research and Development, 52(4), 5-22. 
Wiedenbeck, S., LaBelle, D., \& Kain, V.N.R. (2004). Factors affecting course outcomes in introductory programming. Proceedings of the Sixteenth Annual Workshop of the Psychology of Programming Interest Group (PPIG '04).

Wilson, B.C. \& Shrock, S. (2001). Contributing to success in an introductory computer science course: A study of twelve factors. INROADS of SIGCSE, 33, 184-188.

Yukselturk, E. \& Bulut, S. (2007). Predictors for student Success in an online course. Educational Technology \& Society, 10(2), 71-83.

Yukselturk, E. \& Yildirim, Z. (2008). Investigation of interaction, online support, course structure and flexibility as the contributing factors to students' satisfaction in an online certificate program. Educational Technology \& Society, 11(4), 51-65.

Zimmerman, B. J. (1986). Development of self-regulated learning: Which are the key subprocesses? Contemporary Educational Psychology, 76, 307-313.

Zimmerman, B. J. (1989). A social cognitive view of self-regulated academic learning. Journal of Educational Psychology, 81(3), 329-339.

Zimmerman, B. J. (2002). Becoming a self-regulated learner: An overview. Theory into Practice, 41(2), 64-70.

Zimmerman, B. J. (2008). Investigating self-regulation and motivation: Historical background, methodological developments, and future prospects. American Educational Research Journal, 45 (1), 166-183

Correspondence: Harun Cigdem, Instructor, Turkish Land Forces Non-Commissioned Officer Vocational College, Balikesir, Turkey 